\title{
Maw weber's theory of civilizations today: the rule of law instead of capitalism!
}

\begin{abstract}
Max Weber contributed to all the social sciences: economic history, politics, sociology, law and religion. Of special relevance to globalization studies is his theory about the basic difference between the WEST and the EAST-the so-called Weber's thesis about modern capitalism, based upon his profound inquiries into the world religions, like the religions of India and China, and his studies of the economic history of Europe and the Middle East. His The Protestant Ethic and the Spirit of Capitalism (1904) is the most discussed booklet in the social sciences, endorsed, rejected and falsified, as well as confirmed. I will show that the focus of his comparative studies, viz modern capitalism, is flawed as well as that his major idea in politics, the type of modern legal-rational authority, is more suited for his EAST-WEST civilization approach, but it needs reformulation.
\end{abstract}

Keywords: forms of capitalism, types of authority, world religions, asceticism, western versus eastern religions, rule by law, rule of law
Volume I Issue I - 2017

Jan-Erik Lane
Fellow with Public Policy Institute, Myanmar

Correspondence: Jan-Erik Lane, Fellow with Public Policy Institute;Address: 10 Charles Humbert, I 205 Geneva; 559 A, 3rd Floor, Thuya Street, 9th Quarter, Yangon, Myanmar, Email janeklane@gmail.com

Received: July 06, 2017 | Published: July 10, 2017

\section{Introduction}

The literature on Max Weber is by now large, comprising several biographies and numerous interpretations. ${ }^{1-3}$ All of his publications have been translated into English, the last ones being his major articles in the philosophy of science. ${ }^{4}$ Weber possessed an extreme sensibility for philosophical issues, which allowed him to develop the first modern philosophy of the social sciences. He bypassed German dogmatism, Kantianism and Hegelian Marxism, concentrating instead upon model building, scientific objectivity and neutrality, methodological individualism as well as empirical verification. His basic concept is that of "Sinn", or meaning or intention and "Sinnzusammenhaenge", or meaningful motivation or complex of intensions. The social sciences combine interpretation and statistical corroboration. Some scholars have argued that Weber in reality sought the sources of Western rationalism, ax exemplified in both modern capitalism and the modern bureaucratic state as well as in the sciences. Today, it seems completely impossible to speak of Western rationality as a specific feature of civilization difference. Where, then, can we find a major social system property that separates between civilization legacies, if capitalism and rationality will not do?

\section{Weber's thesis: world religions and modern capitalism}

With so much written about the genius from Freiburg and Heidelberg, it is small wonder that the term "Weber's thesis" stands for a set of themes, not one only., ${ }^{5,6}$ One may clarify this multiplicity by two distinctions:

a) Genetic or systematic theme: Weber's thesis may be about the origins or the pervasive traits of social systems;

b) Religion or civilization theme: Weber's thesis may deal with the outcomes of religious beliefs specifically, or target the basic differences between the cultural civilizations of the world.

Thus, we have a $2 \mathrm{X} 2$ Table, as follows:

a) Religion Civilization b) Genetic I II

c) Systematic III IV

Actually one finds these four themes in the various books by Weber himself, as he wrote in an almost encyclopedic fashion about the history of political, economic and social systems. He singled out "modern" capitalism as his dependent variable, which would give the following list of themes:

a) Modern capitalism arose in the West due to Protestantism (I);

b) Modern capitalism arose in Western rationality (II);

c) Modern capitalism has an affinity with Protestant ethics (III);

d) Modern capitalism is an expression of Western rationality (IV).

I cannot present a summary of the huge debate about these Weberian themes-see Schluchter. ${ }^{5}$ Nor shall I enter any polemics against the critique of Weber from various scholars, economic historians and sociologists for example. ${ }^{7,8}$ If the Protestant Ethic and the Spirit of Capitalism from 1904 (2010) has made Weber's name unforgettable, with new editions coming even some 100 years after, then there are, I claim, three difficulties with Weber's thesis when confronted with today's realities and knowledge.

\section{First problem: what is modern capitalism?}

As his dependent variable, Weber had chosen capitalism. It is quite understandable, given that several scholars in German Academia dealt with the subject. And the ascending Arbeiterbewegung promised another and better economic system, socialism. Yet, it was hardly a fertile choice, as the concept of capitalism is amorphous and the word itself highly value-loaded. Two meanings should be sharply separated:

a) Capitalistic spirit or the acquisitive endeavor. ${ }^{9}$

b) Systems of capitalism, i.e. various institutional set-ups.

Weber obviously used the word "capitalism" in both the micro sense (incentives) and the macro sense (systems of norms). Perhaps he argued that the micro attitudes of the great Protestant 
leaders and personalities were different enough compared with the Catholic Church fathers to pave the way for "modern" macro capitalism, especially in the theory of predestination, considering greed as somewhat of a call? Yet, "modern" capitalism is conceived institutionally as the market economy with bourse: "It is only in the modern Western world that rational capitalistic enterprises with fixed capital, free labor, the rational specialization and combination of functions, and the allocation of productive functions on the basis of capitalistic enterprises, bound together in a market economy, are to be found". ${ }^{10}$ Yet, the institutions of modern capitalism can be exported and adopted by other civilisations, learned and refined, which is exactly what occurred in the $19^{\text {th }}$ and $20^{\text {th }}$ centuries. Thus, even if Protestantism, or the Protestant ethics denying the possibility of magic and accepting rents had something to do with the origins of modern capitalism in the West-i.e. economic rationality or even overall rationality (Entzauberung der Welt), which though remains an essentially contested issue, it could never guarantee any persisting advantage. It is difficult to chisel out an interesting hypothesis about "modern" capitalism and the world religions that would have any relevance today.

Today, modern capitalism, at least when measured in terms of output, is perhaps stronger in South, East and South East Asia, with a few strongholds also within Islam, like for instance the UEL, Kuwait and Qatar. If "capitalism" stands for a set of institutions, or rules, then one may wish to enumerate a number of different types of capitalisms during known history: ancient, state, feudal, prebendal, modern, oriental, financial, etc. Weber displayed in his historical books that he mastered all these types of capitalism as well as that his emphasis upon mundane incentives meant that he always counted upon the role of the acquisitive spirit.

Perhaps Weber neglected the huge pottery factories, driven capitalistically with huge exports, during various dynasties in China, ${ }^{11,12}$ just as Sombart in his effort to link "modern" capitalism with the finance capitalism of the new merchant class around $1500^{13}$ bypassed the Indian Ocean trade. The Arab, Indian and Chinese merchants on the Indian Sea, from Mocha and Aden to Malacca and Canton, were no less capitalistic in spirit or rational in performance. ${ }^{14-16}$ "Modern" capitalism was not as exclusively European as some authors have claimed, following Weber. ${ }^{17-19}$ The famous so-called "thirteen factories" in Canton were capitalistically operated.

\section{Is modern capitalism the "take-off" stage?}

Scholars analyzing capitalism come up with a list of different kinds of capitalism, institutionally speaking, like Sombart ${ }^{13} \&$ Schumpeter. ${ }^{20}$ Weber separated between at least the following kinds:"

a) Ancient Period: trade in slaves and tax farming;

b) Feudal capitalism: exploitation of serfdom as well as fiefs;

c) Merchant capitalism: profit seeking in luxuries trade and political banking, i.e. lending to monarchs for instance;

d) Industrial capitalism $=$ modern capitalism above.

Contrary to Sombart and Schumpeter, Weber never envisioned a final stage of capitalism disintegration, because he rejected the functionality of a pure socialist economy, or the command economy. However, the question of a WSET-EAST split in capitalism remains. If it is a matter of industrial capitalism, then the Rostow theory of the take-off stage is very helpful. If modern or industrial capitalism can be dated in time at all, then Rostow's take-off idea would be the closest-see a stylized listing in Table 1. The interesting observation in Table 1 is of course Japan, experiencing a very fast capitalistic development after the Meiji Restoration, not later than take-off in France and Germany-see The Economic Development of Japan 1868$1941 .{ }^{21}$ The year for China is probably wrong, as there were much earlier developments, especially in Canton. Also India may have to be revised as far as take-off stage is concerned. The evolution of industrial or modern capitalism in South, East and South East Asia needs more study,

Table I:"Take-off "dates for modern capitalism: a few countries.

\begin{tabular}{ll}
\hline Country & Take-off in time \\
\hline Great Britain & $1783-1802$ \\
France & $1830-1860$ \\
Belgium & $1833-1860$ \\
United States & $1843-1860$ \\
Germany & $1850-1873$ \\
Sweden & $1868-1890$ \\
Japan & $1878-1900$ \\
Russia & $1890-1914$ \\
Canada & $1896-1914$ \\
Argentina & 1935 \\
Turkey & 1937 \\
India & 1957 \\
China & 1957
\end{tabular}

Source: http://easyeconomicsforyou.blogspot.ch/2010/07/rostows-stages-ofdevelopment.html

\section{Second problem: the analysis of religion: what are inner worldly and other worldly aspects of religion?}

As his independent variable, Weber chose religion. The first step was to detail the link between Protestantism and capitalism. The second step involved a huge comparative enquiry into the economic spirit or ethics of several world religions in order to show that his thesis received negative corroboration in Hinduism, Buddhism, Taoism and Confucianism. It enhanced the study of comparative religion tremendously beyond what Marx and Durkheim accomplished with their simplistic models of "opium of the people" as well as mechanic solidarity or functional needs. But there is a conceptual paradox in Weber's typology of the world religions. He employed two conceptual pairs:

a) Salvation: Inner or other worldly religion;

b) Asceticism: Inner or other worldly asceticism.

Combining these two, we have the following classification scheme:

a) Salvation

b) "Diesseitig" "Jenseitig"

c) Inner worldly I II 
d) Asceticism

e) Other worldly III IV

A religion that is other worldly has an eschatology outlining the real world to come on judgement Day, whereas an inner worldly religion promises redemption within existing universe. ${ }^{22}$ Asceticism or the perfection of the conduct of performance according to an ideal can be inner worldly here and now or outer worldly as in mysticism. Weber finds the drive for capitalism in the mundanely daily and secular (inner worldly) asceticism of the believers in another worldly religion-category II! No doubt a complex "sinnsu zammenhaege". Where does Islam fit in?

\section{Weber on islam: "virtuosi" and ascetics}

The Koran is eschatological, promising the Paradise to its true believers when this world crumbles. But who are the ascetics? Weber replies: "Islam is a religion of warriors". But warfare and capitalism cannot co-exist for long. Weber employed his model of the ascetics in Islam-the warriors-to account for the incredibly quick spread of Islam, from Spain to India within a century after 632-looting, theft of land and pillage against infidels. Moslem scholars never accepted his model, ${ }^{23}$ because the Islamic civilisation stabilised into a fixed pattern that lasted up until after the Second World War, as follows:

a) Sunni majority with the 5 peaceful rules of behaviour;

b) The many Shia sects with one dominance politically, in Iran;

c) Saudi Arabic Wahhabism, not accepted outside.

What has given Weber's model of Islam much renewed relevance is the rise of fundamentalism, ${ }^{24}$ especially Sunni fundamentalism with three scholars, namely Maududi, Qutb and Faraj ${ }^{25-27}$ Salafi Jihadism. As thousands of young Muslims are attracted to their teachings in madras, schools and colleges or even universities but also prisons, the Koranic civilisation faces a dire civil warfare, resulting in so many deaths and tragedies from political violence, both inside and outside of Arabia. Al-Zawahiri created Al Qaeda writing a book about the "Knights of the Prophet" and al-Zarqawi put the ISIS into action in US and UK occupied Iraq. Moslem theologian and philosophers have yet to come up with a strong rebuttal of the gang of three modern virtuosi (it can be done to save Islam from disintegration!):

a) Maududi: completely comprehensive Islamisation;

b) Qutb: re-invention of the caliphate;

c) Faraj: total jihad-the real hidden duty of Islam.

Much has written about Weber's negative evaluation of Islam and also Muhammad personally. The leading scholar Schluchter ${ }^{28}$ has even ventured to outline how a complete Weberian book on Islam would look like. Some say he was too dependent on the Orientalist literature at that time, missing out on a proper evaluation of Arab science, philosophy, architecture and capitalism, ${ }^{23,29,30}$ bypassing the old virtuosi like giant Averroes and Avicenna.

\section{Third problem: what is legal-rational authority?}

The Governance Project of the World Bank has made a tremendous effort at quantifying the occurrence of rule of law, employing all the indices in the literature-see Appendix in Governance project. The findings are summarized in a scale ranging from +2 to -2 that is a ratio scale. Table 2 presents the aggregated scores for the civilisations, introduced above.

Table 2 Civilisations and Rule of Law

\begin{tabular}{llll}
\hline & Mean & Std. dev. & Freq. \\
\hline Communist & -0.75477 & 0.383265 & 6 \\
Hindu & -0.53253 & 0.642828 & 2 \\
Muslim Non Arab & -0.72383 & 0.656132 & 21 \\
Africa & -0.80077 & 0.621528 & 38 \\
Arab & -0.3038 & 0.715167 & 18 \\
Asia & 0.474797 & 0.963247 & 9 \\
Latin America & -0.18484 & 0.788423 & 34 \\
Orthodox & -0.50738 & 0.355062 & 8 \\
Pacific & -0.18706 & 0.630269 & 16 \\
Western & 1.19717 & 0.667936 & 38 \\
Total & -0.10665 & 0.984421 & 190
\end{tabular}

Typical of legal-rational authority is, I would wish to emphasize, government based upon rule of law. Let us first state the definition of "legal authority" from Weber: "The validity of the claims to legitimacy may be based on: 1. Rational grounds-resting on a belief in the legitimacy of enacted rules and the rights of those elevated to authority under such rules to issue commands (legal authority)" ${ }^{10}$

The key terms in this general definition is rules or institutions. "Today the most usual basis of legitimacy is the belief in legality, the readiness to conform to rules which are formally correct and have been imposed by accepted procedure. The distinction between an order derived from voluntary agreement and one which has been imposed is only relative". The talk about "voluntary agreement" hints at the democratic regime just as the requirement of "accepted procedure". Yet, as is well-known, Weber moves on to equate legalrational authority with bureaucracy: "The purest type of exercise of legal authority is that which employs a bureaucratic administrative staff'. ${ }^{10}$

Yet, bureaucracy as a mechanism for carrying out the policies of rulers has, historically speaking, never operated according to the Weberian ideal-type. Bureaucracies have been invaded by affective ties, embezzlement, tribal loyalties and opportunistic selfishness in search of turf. 20th century research into the bureaucratic phenomenon has resulted in numerous findings that question the applicability of Weber's bureaucracy model. As a matter of fact, bureaucracies can support traditional domination, as within Chinese Empires or Ottoman Ruler ship. It may also figure prominently in charismatic ruler ship, as with The Third Reich or the Soviet State. Weber recognized a fourth kind of political regime that he simple regarded as marginal, namely total authority based on naked power, because it could not last. The question then becomes whether legal-rational authority entails a legitimating rendering it stable over time as rule of law or whether it is enough with rule by law. I find no answer with Weber. The interpretation that Weber was some kind of "fore-runner" to the development of a unique nationalist ideology in Germany in the 1930 s, founding a state upon the exercise of naked power, is, in my view, questionable. ${ }^{31}$ Legal-rational authority implies a constitutional state respecting Kant's Rechtsstaat. As a matter of fact, rule of law trumps democracy, especially plebiscitary democracy. 
The key terms: "beruf", "rationality" and "authority"

The link between Protestantism and modern capitalism is theorized in two different hypotheses, one by economic historians and political scientists and the other by sociologists and globalisation scholars. Thus, we have:

a) Call: Protestantism would have supported the emergence of modern capitalism by its work ethic, underling this worldly asceticism, although the personal goal is other worldly salvation. However, modern capitalism is much more complex than this, especially institutionally. And similar ideas may be found in Buddhism and Confucianism.

b) Rationality: Protestantism would have inaugurated the crushing of outer worldly asceticism, especially the set of magic behaviours and rites, opening up for secularization. However, Protestantism fought hard against Western secularization and lost. The basic source of Western rationality is Greek philosophy and Roman law, not Calvinism and Lutheranism. One finds elements of rationality in the other civilisations, like medicine, astronomy and mathematics with Muslims, mathematics with Hinduism plus scientific innovations and technology in China However, one does not find the idea of rule of law and limited government outside of Western Europe, due to the predominance of oriental despotism.

c) Authority and Naked Power: Weber was well aware of the place of power in social systems, as the capacity to impose ones will against another. However, he argued that power is fundamentally instable as well as that the employment of naked power is costly. Thus, we have his theory of three bases of political legitimating, enhancing authority as obedience. This moral dimension could be filled with tradition as in oriental despotism, charisma or the extraordinary gift to give direction and public law, i.e. constitutions and administrative law. In legal-rational authority, is legal-rational authority rule by law, as in China or Russia, or rule of law, as in Europe and India?

Evidently, Weber underestimated the effectiveness and longevity of naked power. It may last for decades as in North Korea, Syria and
Libya or Iraq. Perhaps the only basis of politics that may last is the rule of law, to which we turn now.

\section{Civilisations today: rule of law}

One may employ Figure 1 to portray the same findings as in Table 1. It should perhaps be pointed out that poverty accounts to some extent for the disrespect for due process of law-see Figure 1.

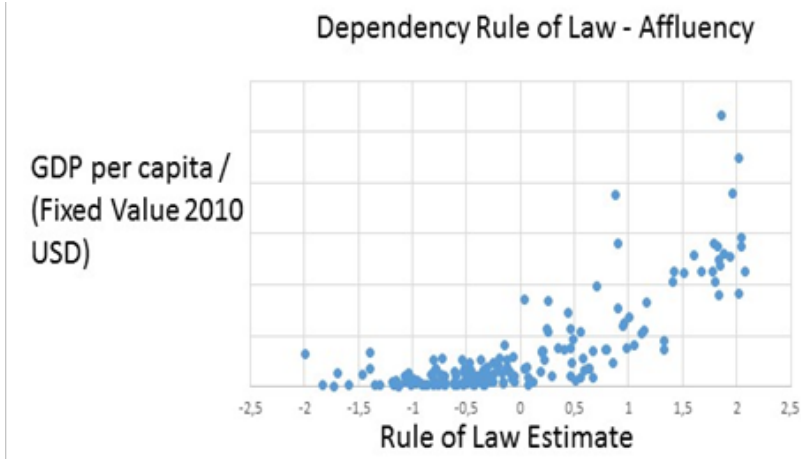

Figure I Rule of law index (RL) against GDP $2015\left(N=\mid 67, R^{2}=0,62\right)$.

Note: WB: Worldwide Governance Indicators, 2016; See Kaufmann D, Kraay A and Mastruzzi M (2010).

"The Worldwide Governance Indicators: Methodology and Analytical Issues". World Bank Policy Research Working Paper No. 5430; World Bank national accounts data; OECD National Accounts data files. However, culture also matters in the form of civilisations, especially Islam and Buddhism, and Orthodoxy-negatively-as well as Calvinism and Lutheranism-positively. RL cannot be introduced or upheld in a country with considerable tribalism and clan structures. Similarly, RL is not feasible in a country where Sharia has constitutional status. In many countries in the African and Asian civilisations there is both ethnic diversity and Islam. One may employ the regression technique in order to examine the impact of these factors upon RL:Ethnicity: The fragmentation of a country into different ethnic groups (language, race);-Religion: The proportion of Muslims in country population; the proportion of Buddhist/Confucians in the country population;-Affluence: GDP in 2010. Table 3 displays the findings from an estimation of a regression equation.

Table 3 Regression model for rule of law (RL) (N=162)

\begin{tabular}{llllll}
\hline & \multicolumn{2}{l}{ Unstandardized coefficients } & \multicolumn{2}{l}{ Standard coefficients } \\
\hline & B Std. & Error & Beta & t & Sig. \\
\hline (Constant) & $-4,216$ & & $47 \mid$ & -8948 & 0 \\
In2010 & 507 & 47 & 657 & 10847 & 0 \\
Ethnic & -474 & 222 & -126 & -2139 & 34 \\
Muslim & -3 & 2 & -118 & -2192 & 30 \\
budd2000 & -2 & 3 & -27 & -5147 & 606 \\
R & R Square & Adjusted R Square & & Std. Error of the Estimate & \\
77 I & 595 & 584 & & 621331 &
\end{tabular}

Sources: Kaufmann DA Kraal and M Mastruzzi (20I2) Worldwide Governance Indicators; Pew Forum (2009) Mapping the Global Muslim Population; World Bank (20I2) World Bank Databank; Barrett D B et al. (200I) World Christian Encyclopaedia. 


\section{Why rule of law?}

Rule of law, whether combined with any form of democracyreferendum type, parliamentary type, presidential dispensation-or not, as in semi-democratic countries that are one party states. Comprises ${ }^{32}$

\section{Predictability}

Public law when properly implemented makes it possible for people to increase the rationality of behaviour. They know what rules apply, how they read as well as how they are applied consistently. This is very important for the making of strategies over a set of alternatives of action.

\section{Transparency}

Societies operate on the basis of norms prohibiting, obligating or permitting certain actions in specific situations. Rule of law entails that these norms are common knowledge as well as that they are not sidestepped by other implicit or tacit norms, known only to certain actors.

\section{Due Process of Law}

When conflicts occur either between individuals or between persons and the state, then certain procedures are to be followed concerning the prosecution, litigation and sentencing/incarceration. Thus, the police forces and the army are strictly regulated under the supervision of courts with rules about investigations, seizure, detainment and prison sentencing. No one person or agency can take the law into their own hands.

\section{Fairness}

Rule of law establishes a number of mechanisms that promote not only the legal order, or the law, but also justice, or the right. For ordinary citizens, the principle of complaint and redress is vital, providing them with an avenue to test each and every decision by government, in both high and low politics. Here one may emphasize the existence of the Ombudsman, as the access to fairness for simple people. People have certain minimum rights against the state, meaning that government respects obligations concerning the protection of life and personal integrity. Thus, when there is due process of lawprocedural or substantive-one finds e.g. the habeas corpus rights.

I would dare suggest that most people in the world would want to live in a country where these precepts are respected and enforced. Only human sufferings result when they are not. Even people who adhere to a religion that rejects rule of law regret their absence when trouble starts and anarchy or even warfare comes. Rule of law I the greatest idea in the history of political thought, from Cicero (very underestimated) to Kant.

\section{Conclusion}

The civilisation deviate the most from the Rechtsstaat is the Moslem one. This is due to the un-recognised and not fully understood revolution in the mind sets that we call Sunni fundamentalism or radical Islam. It now has started to appear in many Western countries with dire effects. Yet, rule of law is weakly enforced in the Latin American civilisation, non-existent in the Sub-Saharan civilisation and not very frequently occurring in the Buddhist one with its legacy of Oriental despotism, ${ }^{33,34}$ occurring also in the Moslem civilisation as Sultanismus, although not always with a hydraulic foundation..$^{35}$ Even in Japan and South Korea like in Taiwan and Singapore, rule of a law is not complete, and in the former Soviet republics, the situation could not be worse.

Today, Weber would have wished to take rule of law instead of capitalism as his dependent variable. After all, much of his writings belong to political science proper. Thus, let us turn to Weber's chief accomplishment in political sociology, namely that he identified four types of political regimes: naked power, traditional, charismatic and legal-rational authority-a most often used typology also today. However, he was not clear about the nature of the last type, linking wrongly-I wish to argue-legal-rational authority with his idealtype Rule by model of bureaucracy, which may appear also in the authoritarian political system. Rule by law in China is not to be clustered conceptually with rule of law in the UK and the US.

\section{Acknowledgements}

None.

\section{Conflict of interest}

The author declares no conflict of interest.

\section{References}

1. Bendix R. Max Weber-An Intellectual Portrait. USA: University of California Press; 1960.

2. Bendix R, Roth G. Scholarship and Partnership: Essays on Max Weber. USA: University of California Press; 1971.

3. Ringer F. Max Weber: An Intellectual Biography. Chicago: University of Chicago Press, USA; 2004.

4. Bruun HH, Whimster S. Max Weber: Collected Methodological Writings. London: Routledge, UK; 2012.

5. Schluchter W. The Rise of Western Rationalism: Max Weber's Developmental History. USA: University of California Press; 1992.

6. Albert G, Bienfait A. Aspekte des Weber-Paradigmas: Festschrift für Wolfgang Schluchter. Albert G, Bienfait A, editors. Verlag für Sozialwissenschaften. 2007.

7. Samuelson K. Religion and Economic Action. A critique of Max Weber. USA: Harper Torchbooks; 1964.

8. Tawney RH. Religion and the Rise of Capitalism. Verso, USA; 1930.

9. Tawney RH. The Acquisitive Society: Greed and Society. UK: CreateSpace Independent Publishing; 1922.

10. Weber M. Economy and Society I-II. USA: University of California Press; 1978.

11. Vainker SJ. Chinese Pottery and Porcelin. UK: British Museum Press; 1995.

12. Glahn von R. The Economic History of China. UK: Cambridge UP; 2016.

13. Sombart W. Economic Life in the Modern Age. USA: Transaction Publishers Piscataway; 2001.

14. Kumar D, Desai M. The Cambridge Economic History of India. UK: Cambridge UP; 1983.

15. Um P. The Merchants of Mocha. USA: University of Washington Press; 2009.

16. Chaudhuri K. Trade and Civilisation in the Indian Ocean: An Economic History from the Rise of Islam to 1750. UK: Cambridge UP; 2010. 
17. Beaud M. A History of Capitalism 1500-2000. Delhi: Aakar Books; 2006

18. Neal L, Williamson JG. The Cambridge History of Capitalism. UK Cambridge UP; 2015.

19. Kocka J. Capitalism: A Short History. USA: Princeton UP; 2016.

20. Schumpeter AJ. Essays: On Entrepreneurs, Innovations, Business Cycles and the Evolution of Capitalism. Transaction Piscataway, USA; 1989.

21. Macpherson WJ. The Economic Development of Japan 1868-1941. UK: Cambridge UP; 1987.

22. Glasenapp von H. Die fünf grossen Religionen: Two volumes. Dusseldorf/ Köln: Diederichs, Germany; 1952.

23. Rodinson M. L'islam: Politique et croyance. Fayard, Paris, France; 1993.

24. Davidson L. Islamic Fundamentalism: An Introduction. Praeger, USA 2013.

25. Calvert J. Sayyid Qutb and the Origins of Radical Islamism. C Hurst, London, UK; 2010.

26. Jackson R. Mawlana Mawdudi and Political Islam. Routledge, London, $\mathrm{UK} ; 2010$.
27. Manne R. The Mind of the Islamic State: Milestones Along the Road to Hell. Black Inc. Redback, Australia; 2016.

28. Schluchter W. "Hindrances to Modernity: Weber on Islam”. In: Huff, Schluchter, editors. 1999. p. 26-58.

29. Huff TE, Schluchter W. Max Weber and Islam. USA: Transaction Publishers; 1999.

30. Risso P. Merchants and Faith. Boulder, USA: Westview Press; 1995.

31. Mommsen WJ. Max Weber und die deutsche Politik 1890-1920. Mohr und Siebeck, Tuebingen, Germany; 2004

32. Raz J. The Authority of Law. UK: Oxford UP; 2009.

33. Weber M. Economie et société dans l'Antiquité. La Découverte Routledge, Paris, France; 2001.

34. Weber M. General Economic History. Dover, USA; 2003.

35. Wittfoget K. Oriental Despotism. Yale UP, New Haven, USA; 1957. 